\title{
Training in service: perception of health workers in assistance in federal prison units
}

\author{
Capacitação em serviço: percepção dos trabalhadores de saúde na assistência em unidades \\ prisionais federais \\ Capacitación en servicio: percepción de los trabajadores de salud en la asistencia en unidades \\ prisionales federales
}

\author{
Lana Jocasta de Souza Brito ${ }^{1}$ (ii) \\ Silvia Helena Henriques ${ }^{1}$ (iD \\ Cléria Bragança ${ }^{2}$ (ID) \\ Laura Andrian Leal ${ }^{1}$ (iD)
}

1. Universidade de São Paulo, Escola

de Enfermagem de Ribeirão Preto.

Ribeirão Preto, SP, Brasil.

2. Centro Universitário do Triângulo.

Uberlândia, MG, Brasil.
Corresponding author:

Laura Andrian Leal.

E-mail: laura.andrian.leal@usp.br

Submitted on 05/29/2019.

Accepted on 08/21/2019.

DOI: 10.1590/2177-9465-EAN-2019-0158

\begin{abstract}
Objectives: To characterize the in-service training process of health workers from federal prison units. Method: This is a qualitative descriptive-exploratory study. The information was collected through semi-structured interviews with professionals of the referred services, from June to October 2018. Results: Data analysis revealed that health professionals were unaware of the work performed within these establishments and that the concern of these institutions by the improvement of these workers is recent and marked by isolated actions. Of the courses offered, few contemplate the reality of prison health causing the server to seek knowledge on their own. Due to the violent and confining environment, the health team lacks courses such as defense and weaponry. Conclusions and implications for practice: The study reveals flaws in the training strategies offered by the organization and incipient managerial awareness about the professional and emotional preparation of these workers.
\end{abstract}

Keywords: In-service Training; Prisons; Patient Care Team.

\section{Resumo}

Objetivo: Caracterizar o processo de capacitação em serviço dos trabalhadores de saúde que atuam em unidades prisionais federais. Método: Trata-se de estudo descritivo-exploratório e qualitativo. As informações foram coletadas por meio de entrevista semiestruturada junto a profissionais dos referidos serviços, entre os meses de junho e outubro de 2018. Resultados: A análise dos dados revelou que os profissionais de saúde desconheciam acerca do trabalho executado no interior de tais estabelecimentos, cuja preocupação pelo aprimoramento desses trabalhadores é recente e marcada por ações isoladas. Dos cursos oferecidos, poucos contemplam a realidade de saúde prisional, fazendo com que o servidor busque conhecimento por conta própria. Devido ao ambiente violento e confinador, a equipe de saúde carece de cursos, tais como defesa e armamento. Conclusões e implicações para a prática: $O$ estudo revela falhas nas estratégias de capacitação oferecida pela organização e sensibilização gerencial incipiente acerca do preparo profissional e emocional desses trabalhadores.

Palavras-chave: Capacitação em serviço; Prisão; Equipe de Assistência ao Paciente.

\section{Resumen}

Objetivos: Caracterizar el proceso de capacitación en servicio de los trabajadores de la salud de las unidades penitenciarias federales. Método: Este es un estudio cualitativo descriptivo-exploratorio. La información se recopiló a través de entrevistas semiestructuradas con profesionales de los servicios referidos, de junio a octubre de 2018. Resultados: El análisis de datos reveló que los profesionales de la salud desconocían el trabajo realizado en estos establecimientos, cuya preocupación por la mejora de estos trabajadores por parte de estas instituciones es reciente y está marcada por acciones aisladas. De los cursos ofrecidos, pocos contemplan la realidad de la salud de la prisión, lo que hace que el servidor busque conocimiento por su cuenta. Debido al ambiente violento y confinado, el equipo de salud carece de cursos como defensa y armamento. Conclusiones e implicaciones para la práctica: El estudio revela fallas en las estrategias de capacitación ofrecidas por la organización y una incipiente concienciación gerencial sobre la preparación profesional y emocional de estos trabajadores.

Palabras clave: Capacitación en Servicio; Prisión; Grupo de Atención al Paciente. 


\section{INTRODUCTION}

The health-disease process of a specific group is the result of mutual influence of social, economic, cultural, environmental and political determinants, other than interaction between the team professionals and the users. So, health care requires knowledge and professional training that allows them to reflect, dialogue and construct competencies about the different work contexts and their contradictions, as well as their needs, challenges and expectancies in accordance with the communities in the assisted territories. ${ }^{1}$

The population assisted by the health professionals in prisons are persons deprived of liberty. These individuals' $s$ health is directly influenced by the prison environment, which is marked by adverse conditions, such as: prison units overcrowding, bad hygienic conditions, presence of infectious diseases such as tuberculosis and human immunodeficiency virus ((HIV), mental disorders, substance abuse, leisure, absence of formal and innovative work, aggressions victimization and violence perpetration, the latter being one of the more relevant health grievances to the prisoner's health. ${ }^{2}$

In that sense, the health worker should have technical knowledge inherent in its profession allied to the specific knowledge of the prison environment and the assisted population (in custody) - that require peculiar and own demands, in order to perform and carry out their tasks better. ${ }^{3}$ In this regard, is vital the investment in the human talent and in-service training.

According to the Decree No. 5.707, of 23 February 2006 - that institutes the Policy and the Guidelines for the Personal Development of the direct public administration, autarchic and foundational, which includes the servers who work in federal prisons -, to enable is the permanent process and deliberate of learning, in order to develop and improve individual competencies necessary for its actuation in the context in which it is professionally situated. ${ }^{4}$

So, the training of these workers helps in developing competencies- that is, knowledge, skills and attitudes essential for the qualification of this professional facing the work context challenges -, as well as for the qualification of the work process, resulting, at last, in effective care and service providing. ${ }^{5}$

Moreover, as provided for in Law No. 11.907/2009, of 2 February 2009 - that regulates the careers of the federal penitentiary area, the National Penitentiary Department (DEPEN) of the Ministry of Justice (MJ) -, they are responsible for setting up training programs in order to ensure the professionalization of their workers. ${ }^{6}$

That way, the National Health Plan in the Penitentiary System (PNSSP) also reveals the importance of the establishment to qualify health professionals, the professional servers of the prison system and health promotion agents, in order to identify the most recurring and important problems in the universe of the persons deprived of liberty, by aggregating curative actions and of primary health care that implement the integral care, the qualification and the humanization relating to the health in the prison system. ${ }^{7}$
In relation to health workers, the Federal Penitentiary System (SPF) presents the following composition of positions: Federal Specialist in Assistance to criminal execution and Federal Technician in support to the criminal execution. The first consists of higher level professionals, such as physicians, pharmacists, nurses, psychologists, dentists, occupational therapists, social workers and educators. In the technician position, the worker has high school education, such as nursing technicians and dental office assistants.

As such, for the improvement of the quality of health services provided in the prison environment, one should encourage and invest in the development of health workers.

From the above, it is questioned: How the qualification or training been occurred for performance of health professionals in prison units? Are specific activities for professional training addressed to the prison environment? Which are the needs for training of these workers?

The analysis of possible strategies or ways of qualification should trigger reflection of managers and professionals in identifying shortcomings or gaps, in the perfecting process and development of health workers' skills, to exercise activities in the prison context in an effective way.

Therefore, this study aims to characterize the in-service training process of health workers that work in federal prison units.

\section{METHOD}

This is a qualitative descriptive-exploratory study. The study scenarios were federal prison units located in Porto Velho (RO), Catanduvas (PR), Mossoró (RN) and Campo Grande (MS). During the research data collect, only these four prison units were in full operation; that is, had prisoners, workers, custody and care. The unity of Brasília (DF) was not included in the scenario because it was recently inaugurated (October 2018), where, only in February 2019 - that is, in the final preparation stage of this research-the first prisoners were moved to that unit and, with them, the health workers.

It is also important to point out that there is a project to build a federal prison unit in Charqueadas (RS), however it is not in the process of implementation; therefore, making its inclusion unfeasible in the study scenario. Every unit has the capacity for 208 prisoners, and the architectonic configurations are similar among the four units. In this prison units, there are places of provision of health services where specialists and technicians work.

The health workers who worked in four prison units participated in the study. Among them, specialist professionals (high level education) - physicians (up to the time of elaborating this study, no professional had assumed the position in this category, and there are two vacancies for the position in each unit), 3 pharmacists, 12 nurses, 7 psychologists, 7 dentists, 4 occupational therapists and 5 social workers - and technicians (high school education with technical education) ,- 15 nursing technicians and four dental office assistants. However, the 
study population was composed of health workers inserted in these scenarios, in which 14 (63.6\%) workers had higher level education - six nurses, three dentists, one occupational therapist, one social worker and one psychologist. Eight (45.5\%) were midlevel workers, being seven nursing technicians and one dental office assistant.

As the inclusion criteria, health workers, of both sexes, who worked for more than six months in the system, with workload of 40 hours, either on-duty regime (in this case, nurses and nursing technicians), or full time regime (other health workers).

The first six months were inserted as criteria, since it is a period in that workers, in general, do not have experience in penitentiary health care, they are still situating themselves, experiencing work in a prison, requiring insertion and experience in this universe, aiming at substantiating their own understandings about all conditioning and aspects of the federal penitentiary system. So, it can be deduced that, after this initial period, possibly they can better contribute to a deeper discussion. All the health professionals who work in the system (penitentiary specialists and technicians) comply with the weekly working hours of 40 hours, even if privately some professions have a lower weekly limit than that. The legal support is set out in the Article 143 of Law No. 11.907/2009, which design the Career of the Federal Penitentiary Agent and of Specialist in Penitentiary Health Care and of Technician of Support to Penitentiary Health Care, among others. $^{6}$

In this study, the number of participants was defined by means of the data saturation. ${ }^{8}$ Data collection occurred from June to October 2018, using semi-structured interview script, composed of closed questions, which allowed us to identify the interviewees, such as gender, age, post-completion academic training time and time in service actuation. Open questions were related to the research theme, being: How has been your preparation or training to work in these units? Which are the training strategies offered by the institution? Which are your needs for training or enhancement?

The recorded interviews had average time of thirty minutes, and were conducted in places chosen by the interviewees and outside the work environment, and subsequently transcribed by the researcher. In addition, they were identified with the letter $E$ of Interviewees, following by the interview number.

The inductive content analysis was used to interpret data of this study. For this purpose, we have opted to use the thematic analysis, which went through the following steps: transcription and reading of data; codification of data interesting characteristics, in a systematic way, in the whole set of data; search for themes by grouping codes; review of themes to verify whether they addressed the coded extracts; ongoing analysis to improve the specificities of each theme; and, at last, final analysis of the selected segments, regarding the research guiding questions and to literature, producing an analysis academic report. ${ }^{9}$

This study was approved by the Research Ethics Committee of the proponent institution (CAAE: 89987718.5.0000.5393). The research was developed according to Resolution No. 466/2012 of the National Health Council. All the participants in the study had their rights assured by signing a Free and Informed Consent Form.

\section{RESULT AND DISCUSSION}

\section{Characterization of the participants}

The population was composed of 22 health workers who worked in Brazilian federal prisons. Data showed population predominantly female, in which $16(72 \%)$ were female and six $(28 \%)$ were male. With respect to age, the results showed that the majority were aged between 31 and 40 , comprising, approximately, $63.3 \%$ of the participants. In addition, four (18.3\%) participants belonged to the youngest age group of professionals, between 25 and 30 years old, whereas four (18.3\%) were more than 40 years old.

Results also showed the significant presence of women in the labor market, mainly in health care, since the care is culturally associated with the inherently female skill. This insertion comes from a trajectory of changes that arose in the industrial period, when the woman, in addition to carry out maternal and domestic functions, started to act in the market.

In relation to the professional category, 14 (63.65\%) workers had higher level education, six of them nurses, three dentists, two pharmacists, one occupational therapist, one social worker and one psychologist. Eight (45.5\%) were mid-level workers, seven of them nursing technicians and one dental office assistant. As for professional training time, it can be observed that $16(72 \%)$ had above 10 years.

The predominance of professionals was higher level and with above 10 years of post-completion training time, which infers that they should have more experience in health area and also denser teaching. With respect to the health professionals' experiences, most had worked in other health institutions, which shows professional experience in the area - although most had already worked as professionals in other places, and this has possibly contributed to the development and enhancement of their technical activities. The prison scenario was unknown to 18 $(81 \%)$ interviewees and, taking into account the federal prison environment, all, without exception, did not know it.

In fact, I didn't know where I was getting into. I wasn't sure what it was, what I was going to work on, I think none of us were sure where we were getting into, about the risks and such. (E5)

As prisons represent spaces of multiple segregations separate the prisoners from the rest of society,$-^{10}$ and without fully elucidative information about the prison reality, it can be understood that the worker coming from society, in general, when entering into custody systems, cannot establish similarity of this context with the other social contexts of greater personal and professional practice. As a reflex, it initially dos not have previous knowledge regarding how he will carry out his work in a so rough environment until it becomes familiar with this system. 
Thus, according to participants, they have never had a curricular health internship in these environments or even had entered into anyone, nor for eye contact of the place. It is well known, as reported in media, the prison is a separate and confining environment; therefore, it is understood that persons subject to this regime suffer from peculiar diseases and specificities that require de appropriateness of practices and health procedures which meet better the needs of this population. That way, the discourses were organized into two categories: Preparation and professional training in federal prison units and Needs for enhancement and physical and emotional training of health workers.

\section{Preparation and professional training in federal prison units}

The professional performance, regardless of the work context, requires the worker to have previous knowledge of its function, of work environment and of the population who will receive support. ${ }^{11}$ Data analysis showed how the trainings provided to these professionals have occurred.

It is necessary to reinforce that, before starting their activities in the prison units, the workers were not aware of the type of work that they should carry out. Hence, in order to approximate this worker of the labor reality of a custody system and better elucidate this work context, the DEPEN - board responsible for these penal federal institutions - provided a professional training course, with workload of around 290 hours/class, which also represented the last step of the public contest for these professionals, in order to prepare them for the work on health within this work environment.

I came to work in the prison unit, the single preparation was in the training course which said which were the risks, that the security was the priority, the health policies for the prisoners (...) (E10)

However, this training had no applicability and connection to health practices found in the workplace, according to the report:

We carried out the training course in Brasilia, but in no way it prepared us for the actual work routine. The course was a course of knowledge with proof about Law, notions of SUS, this did not have much practical applicability. It was not compatible with the reality. (E3)

The training course was very theoretical, with persons who were not part of the board, who did not know very well what was the DEPEN, penitentiary organ. Many came from law enforcement (teachers), they have not the custody in themselves as their daily. (E6)

It was evidenced, therefore, the representation of a gap of training, since the institution when trying to train these workers, their strategy did not contemplate actually the practice reality of these workers. The offer addressed with specific knowledge by the institution might possibly result in improvements and changes in the provided service, at very fast speed to the one that is obtained only by means of the insertion of the professional into the context.

That way, when entering the system, the worker had to search, by means of attempts and errors, in the daily, the best way to carry out its work and develop work methods. Allied to this barrier, the discourses showed that, in some units, it was the first time any professional had been hired; thus, there was no routine established regarding the practices to be carried out. That is, there were no persons who could pass any type of training or knowledge that could better insert them into this context.

(...), we have been discovering, between failure and success and creating our work methods, and this creation of work methods means that the standardization among the prisons does not occur. (E10)

There is no standardization, there are no manuals of procedures, each one created its method and this brings many problems, because the prisoner makes comparisons, there are conflicts. Sometimes, I act in a way then other colleague in another unit no longer (...) what I can do here, in another unit it is not possible (...) then it sometimes, tuns out to be personal, is that professional who is bad or is unwilling. (E12)

The institutions, when planning their training proposals, should consider the clarification and elucidation of norms, routines, manuals of procedures in order to offer security to the worker, help in its decision-making, in addition to grant uniformity to the discourse and transparency in a company's objectives. ${ }^{11}$

Still, regarding the training of professionals to work in their respective prison units, one can notice that the institution offer few courses addressed to the worker's practice and enhancement.

For my position as a dental technician I have taken two or three courses in these eight years. I believe that it is very few, I think there was not much offer regarding doing courses, no. (E3)

When they offer, it is more through EAD (Distance Education) by the SENASP (Public National Security Department), but are not addressed. (E19)

Ineeded a more specific course to take care of a prisoner in an ambulance. If he has an outbreak? Where am I going to take him? What should I do? What should I apply? Who should I contact? This is a thing that they do not foresee inside a prison unit. There are not courses like this. Addressed to the best implementation of the practice. (E1) 
In order to enhance and develop knowledge aligned with the work routine, these professionals request courses and trainings from the responsible board; however, these resources, which depend on the institution approval, are sometimes denied.

I've already requested to participate in the annual dental assistant congress, there are many workshops, with techniques that are being used, because the dentistry is always changing, and it was denied, not authorized by the institution. (E3)

The very small course offering is not an exclusive reality of the federal penitentiary system. Unfortunately, studies indicate that workers that work in the Family Health Strategy (ESF) also report lack of expressiveness in the amount of trainings. It seems to be a recurring phenomenon in the Brazilian public sector. ${ }^{12}$

The professionals also report that the institution concern with enhancing these professionals is still very recent and occurs on a punctual basis, as evidenced in the speech:

Currently there is a greater concern regarding the server training, but during eight years there was no investment in this area (...) to improve our practice, within the system, there was not. About twelve months, more or less, this concern began (...) I think this is because servers from the care career went to work, due to position deviation, in the coordination of human resources and with the expertise of our health area because they are healthcare professionals, more understanding of the importance of these trainings, they began to offer courses (...) (E18)

In this sense, since the concern with the health professionals' training is embrionary and still is in sensitization process and managerial construction, it is noticed the prevalence of disinterested managerial actions, which provokes the worker's individual search on behalf of its enhancement. So, the worker itself seeks to use individual strategies as a way of solving gaps found in its work experience.

Up to now I did not participate in any training course by the DEPEN. I did it outside, not by the work. (E5)

The courses are more in charge of the server look for. (E19)

Corroborating the idea of low managerial sensitization addressed to the health professional's training, and still thinking about its professional training, the worker searches for options to develop its knowledges such as the internet use. What happens, many times, is the carrying out of distance learning courses during periods addressed to rest.

For my practice I sought in the internet and I carried out distance learning courses. (E5)
In days off I take a distance course in my area, because they do not offer courses for changing a tube or make a dressing, for example, and least of all [course]about it in a context with prisoners. (E17)

The plurality of cases, the lack of articulation in integrated networks and the absence of adequate training for professionals, makes challenging the application of precepts of health promotion and the understanding of the illness of specific communities. ${ }^{13}$ Healthcare work does not follow a pre-determined routine of cases and illnesses. There are several suffering conditions resulting from social, emotional and contextual dysfunctions that together lead the individual to fall ill. That sense, it requires the articulation of different knowledges, polyvalence of knowledges and a range of worker's specific skills, in order to understand the health and disease process of a certain niche.

On that basis, the training of health teams that assist the prison population need to consider that this universe of persons has a selective profile of precariousness, vulnerabilities and previous needs which, allied to environmental characteristics of confinement, produce specific illnesses. To this end, the professional training in health should cover knowledge on the daily life and the local practice experiences, so that the purpose of health practice training and improvement of the professionals performance is achieved. ${ }^{13,14}$

The enhancement and training of these professionals should be encouraged by the managers in an attempt to promote a more appropriate care to the population 's social and epidemiological reality, in which this worker is inserted. ${ }^{15}$

The training confers on workers the domain of knowledges, skills and attitudes; that is, skills inherent to its work process, providing better performance in its position. In this segment, although it is important encouraging the acquisition of scientific knowledge by the workers, it is of key importance that the institutions offer trainings tools that provoke changes in the professional practice and in the work organization itself, as the professional development confers on workers greater autonomy and well-being and, consequently, the institution decreases absenteeism indexes, save costs, humanizes the care which results in a better service quality. ${ }^{16}$

The institutions should increasingly invest in trainings, to health professionals, as the labor contexts always change and acquire new challenges. The intellectual skill acquired from new skills, knowledges and practices provokes changes in habits, which reduce risk behaviors and confer occupational security in health care, in addition to influence in the workers' quality of life. ${ }^{17}$

\section{Needs for enhancement and physical and emotional training}

When it comes to prison units, another issue to be analyzed is the need for institutional investment in trainings that help their workers during their activities, within a work environment that produce such physical and emotional insecurity. Some situations that might happen such as, rebellions and attacks, reinforce the 
importance of enhancing workers' skills in attempting of defense faced with some violent event during their work routine.

If any rebellion occurs, I do not know what I do, whether I have to go down, scream or run. I've never received any kind of instruction. (E3)

There was no defense training as the agents had and we are taking the same risks (...) no training was carried out. They (security agents) are trained to protect themselves with pepper spray, arms, self-defense, fight, precaution measures, and we have not had it from the beginning, and no attitude has been taken by the DEPEN administration. (E5)

Each federal prison unit has its security manual, and none of the security manuals say what specialists and technicians should do in case of attack or rebellion, and there is no training for us addressed to this until today (E4)

The care in prison units presents features different from the usual routine of care carried out by health teams. The prison, in general, is an environment identified as hostile, unstable and complex, with particular identity and own context. In the prison scenario, the disrespect for the dignity and rights of the human person is recurrent including regarding the offer of health care. Therefore, this provides crises, continually, resulting from trivial facts, without relevant motivations, in which the law of the strongest is used and the use of violence, that may cause stressful situations which has as the target, above all, the public property and workers of those establishments. ${ }^{18}$

In this context, it can be noted that the work needs of health professionals go beyond structural, material and technical issues. The trainings should also be offered to protect against physical requirements. There is an institutional gap not to see health professionals as potential victims of the violence carried out inside and outside of prisons, this is proven by discourses that reveal there are not, in manuals, instructions addressed to these workers. Due to the specificity of this workplace, the health team requires courses aimed at weaponry, security and self-defense and intelligence training. Therefore, it is clear that the rapid intervention by organizations and public management of the prison system to change this situation and promote a satisfactory, qualified and safe for health professionals.

\section{CONCLUSIONS AND IMPLICATIONS FOR PRACTICE}

The study showed that the health professionals, when beginning their activities in the prison units, were unaware of the type of the work that should be carried out. This is due to the fact that the prison unit is a closed institution in which few persons commonly entered or experience some type of previous work experience in these environments.
Our study revealed that the concern of the SPF in the presentation of the labor reality for these workers was in a specific way. That is, it included bureaucratic aspects of functioning, in a single moment, however there was no concern with the health professionals' training required to get to that place, and how should deal with the clientele during the conducting of their practices.

In addition to face an unknown work context, these professionals had to improvise their labor practices, as, in some units, it was the first time that a certain professional category had been hired and there was no previous routine of work-based practices or manuals of routines and procedures. Without standardization of conducts or practices, the health actions become conflicting, and may produce indisposition with the other subjects in the system.

It should be emphasized that the concern of the institution for the enhancement of workers is recent and fragmented; therefore, characterized by the scarce volume of courses addressed to the health team professional performance, besides low managerial awareness regarding the training for these workers. Thus, initiatives that depend on the approval by the institution, are sometimes, denied, which provokes the worker's individual search for its enhancement.

It is recognized that, with regards to the health workers of prison units, another issue to be analyzed is its personal training to deal within a work environment so physically and emotionally unsafe, as violent occurrences, such as rebellions and attacks, require physical and psychical health of these workers. This was the main training need reported by the interviewees.

So, the health professionals' work needs go beyond structural, material and technical issues. The trainings for these workers should be offered aimed at weaponry, security and selfdefense and intelligence training. Therefore, it should be noted that there are many failures in the planning and strategies of the workers' training by the federal prison management.

This study had the limitation of being conducted with a small number of health workers. It is needed to extend the sample beyond these workers, to know the demands for educational strategies to deal with the different actors who compose this system - such as managers and penitentiary agents -, even in the sense of sensitization and paradigm break about the health work performed. It should also extend the knowledge regarding the health professionals' trainings or qualifications in state prison units, which are known to have less structure and a greater contingent of prisoners to be assisted.

\section{REFERENCES}

1. Tavares MFL, Rocha MR, Bittar CML, Petersen CB, Andrade M. Health promotion in professional education: challenges in Health and the need to achieve in other sectors. Ciênc Saúde Coletiva [Internet]. 2016 jun; [cited 2018 jun 25]; 21(6):17991808. Available from: http://www.scielo.br/scielo.php?pid=S1413 81232016000601799\&script=sci_arttext\&tIng=en DOI: http://dx.doi. org/10.1590/1413-81232015216.07622016 
2. Minayo MCS, Ribeiro AP. Health conditions of prisoners in the state of Rio de Janeiro, Brazil. Ciênc Saúde Coletiva [Internet]. 2016 jul; [cited 2018 jun 25];21(7):2031-2040. Available from: http://www.scielo.br/scielo. php?pid=S1413-81232016000702031\&script=sci_arttext\&tlng=en DOI: http://dx.doi.org/10.1590/1413-81232015217.08552016

3. Viana DM, Nogueira CA, Araujo RS, Vieira RM, Rennó HMS, Oliveira VC. A educação permanente em saúde na perspectiva do enfermeiro na estratégia de saúde da família. R Enferm Cent O Min [Internet]. 2015 may/aug; [cited 2018 jun 25]; 5(2):1658-1668. Available from: http://www. seer.ufsj.edu.br/index.php/recom/article/view/470 DOI: http://dx.doi. org/10.19175/recom.v0i0.470

4. Presidência da República (BR). Casa Civil. Subchefia para Assuntos Jurídicos. Decreto n. 5707, de 23 de fevereiro de 2006. Institui a Política e as Diretrizes para o Desenvolvimento de Pessoal da administração pública federal direta, autárquica e fundacional, e regulamenta dispositivos da Lei n. 8.112, de 11 de dezembro de 1990. Brasília (DF): Casa Civil; 2007.

5. Peixoto LS, Pinto ACS, Izu M, Tavares CMM, Rosas AMMTF. Perception of nurses in relation to training services offered through the service of continuous education. J Res Fundam Care Online [Internet]. 2015 apr/jun; [cited 2018 jun 25]; 7(2):2323-2335. Available from: https:// www.redalyc.org/pdf/5057/505750946012.pdf DOI: http://dx.doi. org/10.9789/2175-5361.2015.v7i2.2323-2335

6. Presidência da República (BR). Casa Civil. Subchefia para Assuntos Jurídicos. Lein. 11907, de 02 de fevereiro de 2009. Estrutura a Carreira de Agente Penitenciário Federal, de que trata a Lei n. ${ }^{-10.693}$, de 25 de junho de 2003; cria as Carreiras de Especialista em Assistência Penitenciária e de Técnico de Apoio à Assistência Penitenciária entre outros. Brasília (DF): Casa Civil; 2009; [cited 2018 jun 10]. Available from: http://www. planalto.gov.br/ccivil_03/_Ato2007-2010/2009/Lei/L11907.htm

7. Costa GMC, Barbosa ML, Celino SDM, Oliveira LV. Perfil demográfico e das condições de trabalho: a realidade das equipes de saúde implantadas em unidades prisionais. Rev Bras Pesq Saúde [Internet]. 2014 oct/dec; [cited 2018 jun 25]; 16(4):13-22. Available from: http://periodicos.ufes.br/RBPS/article/view/11169 DOI: https://doi. org/10.21722/rbps.v16i4.11169

8. Minayo MCS. O desafio do conhecimento: pesquisa qualitativa em saúde. 14ª ed. São Paulo: Hucitec; 2014.

9. Braun V, Clarke V. Using thematic analysis in psychology. Qual Es Psychol. 2006; [cited 2018 jun 25]; 3(2):77-101. Available from: http:// dx.doi.org/10.1191/1478088706qp063oa

10. Barcinski M, Cunico SD. Os efeitos (in)visibilizadores do cárcere: as contradições do sistema prisional. Psicologia [Internet]. 2014; [cited 2018 jun 25]; 28(2):63-70. Available from: http://www.scielo.mec.pt/ scielo.php?script=sci arttext\&pid=S0874-20492014000200006 DOI: http://doi.org/10.17575/rpsicol.v28i2.696
11. Kalyani MN, Jamshidi N, Molazem Z, Sharif F. How do nursing students experience the clinical learning environment and respond to their experiences? A qualitative study. BMJ Open [Internet]. 2019 jul; [cited 2018 jun 25]; 9(7):e028052. Available from: http://dx.doi.org/10.1136/ bmjopen-2018-028052

12. Medeiros ER, Pinto ESG. Experience and professional training in the School Health Program. Rev Esc Enferm USP [Internet]. 2018; [cited 2018 jun 25]; 52:e03378. Available from: http://www.scielo.br/pdf/reeusp/ v52/1980-220X-reeusp-52-e03378.pdf DOI: http://dx.doi.org/10.1590/ s1980-220x2017048603378

13. Maffissoni AL, Vendruscolo C, Trindade LL, Zocche D. Redes de atenção à saúde na formação em enfermagem: interpretações a partir da atenção primária à saúde. Rev Cuid [Internet]. 2018 sep; [cited 2018 jun 20]; 9(3):1-13. Available from: https://www.researchgate.net/ publication/327488376_Redes_de_atencao_a_saude_na_formacao_ em_enfermagem_interpretacoes_a_partir_da_atencao_primaria_a_ saude DOI: http://dx.doi.org/10.15649/cuidarte.v9i3.549

14. Barsaglini R. Do Plano à Política de saúde no sistema prisional: diferenciais, avanços, limites e desafios. Physis [Internet]. 2016 oct; [cited 2018 jun 25]; 26(4):1429-1439. Available from: http://www.scielo. br/scielo.php?script=sci_arttext\&pid=S0103-73312016000401429 DOI http://dx.doi.org/10.1590/s0103-73312016000300019

15. Aidala AA, Cavaliere B, Cinick S. Strategies and Tools for Public Health Workforce Training Needs Assessments in Diverse and Changing Population Health Contexts. J Public Health Manag Pract. [Internet] 2019 sep/oct; [cited 2018 jun 25]; 25(5):490-497. Available from: http:// dx.doi.org/10.1097/PHH.0000000000000803

16. Leal LA, Camelo SHH, Rocha FLR, Vegro TC, Santos FC. A promoção da saúde da equipe de enfermagem no âmbito hospitalar. Rev Rene [Internet]. 2015 sep/oct; [cited 2018 jun 25]; 16(5):762-772. Available from: http://www.periodicos.ufc.br/rene/article/view/2849 DOI: http:// dx.doi.org/10.15253/2175-6783.2015000500019

17. Barbosa ML, Menezes TN, Santos SR, Olinda RA, Costa GMC. The quality of life of health professionals working in the prison system. Ciênc Saúde Coletiva [Internet]. 2018 apr; [cited 2018 jun 25]; 23(4):12931302. Available from: http://www.scielo.br/scielo.php?pid=S141381232018000401293\&script=sci_arttext\&tlng=en DOI: http://dx.doi. org/10.1590/1413-81232018234.09292016

18. Ávila Neto AM, Argolo Junior C, Dória LG, Diniz LAJB. O gerenciamento de crise em rebeliões no sistema penitenciário brasileiro. Rev Eletrônica Direito e Conhecimento [Internet]. 2018 jan/jul; [cited 2018 jun 25] 1(3):193-206. Available from: https://revistas.cesmac.edu.br/index.php/ dec/article/view/707 